\title{
Analysis on the Reform of China's Resource Tax and Its Impact
}

\author{
Li Zhang \\ Xi'an International University, Xi'an, Shaanxi, 710077
}

Keywords: Chinese resource tax reform; impact study

\begin{abstract}
Since the reform and opening-up, China's economy has achieved rapid development. However, the process of economic development has also led to problems of resource shortage and environmental pollution. At present, the establishment of a sound and reasonable resource tax system can not only increase the state's fiscal revenue, but also help to comprehensively and effectively protect natural resources and alleviate resource waste and environmental pollution. Therefore, this paper takes the resource tax reform and its economic impact as the research object, which has positive and practical significance.
\end{abstract}

\section{Introduction}

The shortage of resources has become a global problem. Countries around the world have introduced policies to reform resource taxes to varying degrees. Most countries attribute the ownership of resources to the state or the whole people and establish them through legislation. Since the founding of the People's Republic of China, China's resource tax system has gone through five stages. Although a series of adjustments have been made in succession, they have not fundamentally reformed thoroughly. With the development of the economy, various shortcomings of China's current resource tax have been exposed. For example, the scope of the collection is narrow, the method of levy is unreasonable, and the tax rate is unscientific, which has led to the failure of China to waste resources and damage the environment. The implementation of the scientific development concept has hindered. In addition, the concept of resource conservation has not penetrated the hearts of the people, and the masses have not been made aware of the scarcity and non-renewability of resources. Therefore, in order to maximize the role of the resource tax, many meetings and reports of the party and the state have proposed reform of the resource tax. The 12th Five-Year Plan period is an important period for resource tax reform. However, considering the current actual situation, the types of resources for reform are still limited. It only kicks off the comprehensive reform of resource tax. We will also carry out resource tax in due course. In-depth and thorough reforms.

\section{The Evolution and Current Situation of China's Resource Tax System}

Although after entering the 21st century, China's resource tax system has been in the process of continuous adjustment and improvement, at present, China's current resource tax system is still based on the second generation resource tax system in 1994. The resource tax collection stipulated in the 1994 Provisional Regulations on Resource Tax includes seven kinds of mineral resources such as petroleum, coal, natural gas, non-ferrous metal ore, ferrous metal ore, other non-metallic minerals and salt. In the actual implementation process, resource taxes and resource compensation fees are levied by resource products of tax authorities corresponding to taxes. For the exploitation and use of resources with long renewable periods such as water, forests, lakes, grasslands, oceans and tidal flats on which humans depend, there is no resource tax levy, which cannot effectively and comprehensively protect the sustainable development of natural resources. Sex. Since these resources are not included in the scope of resource tax collection, it is equivalent to "encouraging" producers and mining enterprises, and plundering and exploiting resources with low exploitation and use costs, resulting in serious waste of resources and environmental damage. It can be said that China's current resource tax system contains almost no "ecological tax". In Russia, where the 
resource tax system is relatively complete, resource taxes such as forestry tax, groundwater resources and land tax have been set.

China's current resource tax law stipulates that the resource tax amount of taxable products $=$ the number of resource products $\times$ the tax amount of the resources of the unit resources, of which the quantity of resource products, that is, the sales quantity or the self-use quantity of the resource products. Judging from the current collection of resource taxes, China does not levy taxes on taxable resource products that have been mined but not put into use. This unreasonable taxation method does not require the miners to bear the tax burden or the cost for the large backlog of products and "cuttings" formed during the resource exploitation process. As a result, the invisible resources are promoted by disorder and low efficiency, resulting in waste of resource products and destruction of the ecological environment. At the same time, enterprises do not have to pay resource taxes for hoarding resource products, which can reduce their own tax costs, or when the price of resource products is low, when the price of resource products rises, the products are hoarded to obtain high profits. At the same time, with the development of the market economy, the price of resource products is mostly determined by market supply and demand. This quantitative method of taxation makes the amount of resource tax paid out of line with the market price of resources. Judging from the bill for resource tax adjustment in China, the tax rate adjustment of resource tax is seriously out of balance with the price increase of resource products. For example, in the first quarter of 2008, the non-taxable price of $5,800 \mathrm{kcal} / \mathrm{kg}$ of thermal coal in the Datong area of Shanxi Province was 380-400 yuan per ton, which was 50-60 yuan higher than that at the end of 2007. Coking coal increased from RMB 351/ton in 2007 to RMB 1014/ton. In 2007, the unified coal resource resource rate in Shanxi Province was 5-15 yuan/ton for thermal coal and 15-20 yuan/ton for coking coal [13]. From the perspective of resource industry, resource tax cannot effectively adjust the profit difference between different enterprises due to the supply and demand of resource products market.

\section{China's Resource Tax Reform Target at the Present Stage}

According to the definition of resource tax, the scope of resource tax collection should include natural resources owned by the state. In fact, China's 1994 Resource Tax Act is limited to the collection of resource taxes on seven resources. Therefore, in order to effectively protect natural resources, reduce waste of resources, and curb environmental pollution, China should gradually expand the scope of taxation of resource taxes, and make all non-renewable resources with long resource regeneration cycle and difficult resource recycling, and renewable resources. Renewable resources with long cycle and high cost, as well as scarce resources in China, are included in the scope of taxation. From the perspective of China's economic development on resource consumption and the current inefficient use of resources, China should include waste and destruction of serious forest resources, water resources, land resources, grassland resources, marine resources, and geothermal resources into resource taxes. Collection scope.

The reform of the resource tax system has always been one of the controversial topics in the field of taxation research. The academic circles are all around, the collection of resource taxes is changed to ad valorem, or from resource reserves, or from profit collection, or both from the ad valorem and the ad valorem. However, with the end of the Central Xinjiang Work Forum on May 19, 2010, Xinjiang took the lead in becoming a pilot of resource tax and fee reform. The crude oil and natural gas resource tax was changed from the quantitative levy to the ad valorem, to the actual taxable products. Sales are taxed on the basis of taxation. This pilot reform of the country shows that the levy of resource tax has become a foregone conclusion.

Although the resource tax is levied at an ad valorem, the tax is directly linked to the market price of the resource products, which regulates the differential income between the resource mining enterprises and improves the efficiency of resource use to some extent. However, when the price of resources rises, the state can increase the tax rate and share more benefits with the company. Therefore, the ad valorem can not be used "one size fits all", that is, all natural resources are levied at the ad valorem basis. Natural resources are renewable and non-renewable. On the one hand, for 
renewable natural resources such as forests, water, grasslands, etc., with their sales as the basis for taxation, the more consumption and use, the more taxes are paid. The increase in the opportunity cost of using the resource product is conducive to regulating the market supply and demand of such resource products, guiding the consumption behavior of enterprises and consumers, and conducive to the sustainable use of natural resources.

\section{The Impact of Resource Tax Reform}

Since the "11th Five-Year Plan", China's regional economic development has basically shown a pattern of "fast economic growth in the central and western regions and slow economic growth in the eastern region." From 1987 to 2000, in terms of the average annual growth rate of GDP, the eastern region was on average two percentage points higher than the central and western regions. In 2009, the economic growth rate of the western region has not declined, but it has increased by $13.4 \%$ compared with 2008. The growth rate has exceeded $10 \%$ for 8 consecutive years and has become the third high growth since the reform and opening up [18]. The resource tax reform plays a more direct and crucial role in maintaining stable and rapid economic development in the central and western regions, developing intensive resource enterprises and mineral resources processing industries, and improving resource utilization efficiency. The reform and improvement of the resource tax is conducive to transforming the resource advantage into an economic advantage in the central and western regions, promoting the transformation, upgrading and optimization of the industrial structure in the central and western regions, developing a recycling and green economy, and conducive to the protection and restoration of the ecological environment. It is conducive to improving the quality and efficiency of economic growth, better promoting economic development in the central and western regions, and narrowing the gap between regions.

The distribution of natural resources in China is uneven. The mineral resources in the central and western regions are rich and concentrated, while the mineral resources in the eastern regions are relatively scarce. However, with the development of China's economy, the implementation of the "West-East Gas Transmission" and "West-to-East Power Transmission" projects, the economic development of the eastern region of China is far ahead of the central and western regions. On the one hand, China's industrial pattern is mainly based on deep processing in the eastern region, and the supply of resources in the central and western regions is the main. In terms of industrial chain, the central and western regions are the "upstream enterprises" in the eastern region, limited to the original output of mineral resources. Or primary processing output. On the other hand, in the central and western regions, processed products and finished products are purchased from the eastern region at high prices. In addition, due to various shortcomings of China's current resource tax system, the low resource tax rate makes the mineral resources as the initial production factor low. It can be said that the low-quality superior resource products in the middle and western regions with backward economic development have fed back the economically developed East area. Therefore, for the central and western regions, the resource tax reform has truly combined the mineral resource prices as the initial production factors with the market demand. Through the market supply and demand mechanism and price mechanism, the factor producers, one of the market players, have gained their status. Raising, in the face of strong demand, its bargaining power has also been improved, so that the true value of mineral resources has been reflected fairly and fairly, and it also truly reflects the "scarcity" of resources. It can be said that the reform of resource tax will change the situation that the demand for mineral resources is strong, while the price of mineral resources is low. At the same time, the marketization of resource product prices is conducive to the optimal allocation of mineral resources, improving the utilization of resources and reducing the waste of mineral resources, which will change the dilemma of "the richer the resources and the more backward the economy” in the central and western regions.

The financial capacity of a country or region depends on the economic development of that country or region. In theory, due to China's extensive economic growth mode and high consumption of resources, the central and western regions are the energy bases for China's economic development, so the financial resources of the central and western regions with abundant natural 
resources should be strong. In fact, the financial capacity of the central and eastern regions lags far behind the eastern region. The reason is that the current resource tax system does not give full play to the distribution of resource income, and fiscal revenue is the primary problem that restricts the development of the central and western regions. Therefore, appropriately raising the resource tax rate and increasing the fiscal revenue of local governments have far-reaching significance for local social and economic development. The increase in fiscal revenue of local governments, on the one hand, provides financial support for the establishment of resource and environmental compensation mechanisms, which is conducive to restoring and improving the ecological and environmental damage caused by resource exploitation; on the other hand, improving the ability of local government investment and transfer payments. It is conducive to the construction of local infrastructure and the improvement of the "people's livelihood" project, so that local residents can share some of the resources and improve their living standards. Through government investment and transfer payments, the distribution of resource revenues between the government and the masses will become possible, and the gap between social and economic development in the region will be further narrowed.

\section{Conclusion}

The reform and improvement of the resource tax system is a gradual process. The reform direction of resource tax should focus on expanding the scope of collection, improving the basis for calculation, adjusting the tax rate, and establishing a multi-functional resource tax revenue distribution mechanism. At the same time, in the implementation of resource tax reform, we should combine the advantages and disadvantages of resource tax reform on the advantages and disadvantages of regional economy, resource provinces, resource-based enterprises and non-resource-based enterprises and consumers, and determine the rational path of reform so that resource taxes can be made to promote China. An important means of economic growth mode transformation, economic restructuring, industrial structure optimization and upgrading.

\section{References}

[1] Liu Shengwang. Analysis of the Effectiveness of Resource Tax Reform-Based on the Perspective of New Institutional Economics [J]. Economic issues, 2009 (1).

[2] Liu Xiaofeng. Comparison and reference of the "BRIC" resource tax [J]. Accounting Research 2009(1)

[3] Ma Wei. The gap between resource tax and regional financial capacity - the experience of federal countries [J]. Tax Research, 2004 (1).

[4] Yan Hua, Du Fang. Research on the impact model of enterprise taxation based on resource tax [J]. Financial Research, 2010 (1).

[5] Ren Jiabao. Suggestions on improving the resource tax reform program [J]. Contemporary Economy, 2009 (3). 